\title{
Threats in Livelihoods among Adult
}

\author{
Keshab Pd. Timalsina \\ Lecturer, Sociology, Makwanpur Multiple Campus \\ Email: timalsina.keshab73234@gmail.com
}

Received: November 20, 2020; Revised \& Accepted: January 25, 2020; Published: February 18, 2021

(C) Copyright: Timalsina (2021).

\begin{abstract}
This is a study entitled "threats in livelihood among adult". A major purpose of this study is to assess the level of the threats of livelihood in the near future among the adults. The study was carried out among the Facebook users who were connected with the researcher's account having at least +2 completed. This is a quantitative study and used cross-sectional descriptive research design to answer research question. Among the users, 113 were selected randomly and survey form prepared in google form share to them for data collection. Researcher succeeded in gathering data from 100 respondents with a 88.5 percent response rate. Collected data were analysed through quantitative methods like; frequency distribution, diagrams, etc. and MannWhitney $U$ test and Chi-square test are applied to test the hypothesis formulated in the study. The study found the highest responses from age group 20-24 which consists of 38 percent. Similarly, the study found the highest percentage (54\%) in the Brahmin group in the caste/ethnic character of the population and Hindu group in religious characteristics. About 84 percent population used the Nepali language as a mother tongue. Furthermore, about 35 percent study population found completion of Master's level education and about 47 percent population reported that work problem is the major reason for not involving a further higher level of education. From the study, it is found that all the individuals of the study population has threats of livelihood in the near future. That treats found high in the factor of increasing the price of goods and services but in all the factors threats of livelihood found the medium. The statistical test proved that there is no significant association between threats in livelihood and caste/ethnicity of the study population. Similarly, the study also found that the average level of threats in livelihood does not vary by male and female.
\end{abstract}

Keywords: Caste/ethnicity, Males-females, rising price, Threats in livelihood, Youth-adult.

\section{BACKGROUND}

When asked "what is a livelihood", few would struggle to answer. "Making a living", "supporting a family", or "my job" all describe a livelihood. The popular meaning of livelihood 
comprises the means of living and sustenance (Chambers \& Conway, 1992). From an economic point of view, livelihood could be the organization of productive means and resources of individuals to maximize their standard of living (Nair, Paul, \& Menon, 2007). The term is well recognized as humans inherently develop and implement strategies to ensure their survival (Havrda et. al, 2017). The concept of livelihoods has gained importance and pulls in recent years through debates about rural development, poverty reduction, and social protection. Chambers and Conway (1992, p. 5) states the definition of sustainable livelihood as:

...comprising the capabilities, assets (including both material and social resources) and activities required for a means of living. A livelihood is sustainable when it can cope with and recover from stresses and shocks and maintain or enhance its capabilities and assets both now and in the future, while not undermining the natural resource base.

A variety of definitions of livelihood are offered in the literature, including, for example, the means of gaining a living or a combination of the resources used and the activities are undertaken to live (Karki, 2021). A livelihood comprises capabilities, capitals (stores, resources, claims, and access), and activities required for a means of living, including food and income. Assets include several elements, some of which represent the economic categories of capital and others, and access to resources. Several studies (Scooner, 1998, Bebbington, 1997; Bebbington, 1999, Carney, 1998, Serageldin \& Steer, 1994) claim that there are five categories of assets. They are natural assets, physical assets, human assets, financial assets, and social assets.

A livelihood is considered sustainable if the individual or the household can cope with and recover from stress and shocks, maintain or enhance capabilities and capitals, and provide sustainable livelihood opportunities for the next generation. And further contribute net benefits to other livelihoods at the local and global levels and in the short and long-term (Su, Saikia, \& Hay, 2018). International organizations such as the United Nations Development Programme (UNDP) and the UK's Department for International Development (DFID) have made extensive use of a variety of sustainable livelihood analysis frameworks to address key issues and links between development and poverty.

Livelihoods are formed within social, economic and political contexts. Institutions, processes, and policies, such as markets, social norms, and land ownership policies affect our ability to access and use assets for a favorable outcome. As these contexts change they create new livelihood obstacles or opportunities (Havrda et. al, 2017).

Many studies found that educated youths are at the risk of unemployment. Due to the increasing population rapidly, the unemployment rate got accelerated and many economic and social threats are increased among educated youth and adult's life (Serrat, 2017).. Furthermore, it is easily projected that if the situation will continue the threats of livelihood become very high soon among the youth's livelihood. So, this study took some of the important socio-economic aspects such as employment, income, violence, assets safety of school-going children and 
women, family breaks up, etc in the youth's life that will probably be occurred in near future for measuring the threats in livelihood.

Based on above background, I am going to highlight the major research gap here. There are many research and academic writing about the current problem related to human life, its causes and consequences but study about the perception regarding probable threats in livelihood those to be observed among educated adult in future life is very rare. It is the major research gap which I want to fill through this study.

\section{RESEARCH QUESTIONS}

This study seeks to answer the following question:

- Do threats in livelihood vary by sex?

\section{THE HYPOTHESIS OF THE STUDY}

For the study the following hypothesis are set up:

1. Ho: Average level of threats in livelihood does not significantly vary by male and female.

H1: The average level of threats in livelihood significantly varies by male and female.

2. Ho: There is no association between threats in livelihood and caste/ethnicity of the study population.

H1: There is association between threats in livelihood and caste/ethnicity of the study population.

\section{PURPOSE OF THE STUDY}

1. To assess the level of the threats of livelihood in the near future among the adults.

\section{OPERATIONAL DEFINITION}

Simply we understand that adult is the person above 18 years of age. The adulthood is divided into three sub-divisions namely; early adulthood (youth), middle age and old age. For the study, I have used adulthood as the group of people having age 20-59 years of age who have completed at least +2 level of education. Similarly, threats in livelihood include the probable challenges such as employment, income, violence, assets safety of school-going children and women, family breaks up, harassment by employer, police and politicians, natural calamities, future old age life, etc. that will likely be seen in the near future among the youth's life.

\section{METHODS}

This study used cross-sectional descriptive research design. This is a quantitative method so, this study followed positivist research paradigm. So, all methods used in this study followed scientific paradigm of social research. This study was based on probability sampling. In the Facebook friend list of the researcher, 3509 friends were listed. Among them, 617 friends were found eligible for the study based on online presence status and eligibility criteria for the study. 120 friends were determined as a sample for the study by using n' $=1.962^{2} * \mathrm{P}(1-\mathrm{P}) /($ standard error $)^{2}$ formula of determining sample size and further the size adjusted by known population and 15 percent non-response rate. For the study 50\% prevalence and 10 percent standard error 
were assumed for determining sample size due to lack of relevant study about it. Sampling elements were selected through lottery method as a method of probability sampling for the study and data collection tool was sent to them through Face book messenger. To meet the need of research objective required data were collected from the self-constructed tool developed in the Google form. The link of Google form was sent to the friends based on their online presence as mention in the sampling technique part. Continuously by making follow up for four days, 100 friends gave responses then after response accepting button made off by the researcher. The collected information was analyzed for fulfilling the objectives of the study. Quantitative tools are used to analyse the data in this study. The response rate of the study was 88.5 percent only. So, in the study distribution of respondents information was made from 100 responses. SPSS used for analyzing and managing the data. Percentage frequency, some diagrams were used for analyzing the result. Similarly, the Mann-Whitney U Wilcoxon W and Kruskal Wallis test was used as a statistical test for analyzing the data.

\section{RESULTS AND FINDING}

\section{A. Socio-economic characteristics of study population}

In the study information about the age and sex of the respondents was also collected. The presented in Table 1 highlights that largest number of study population was found in below 30 years of age. It shows about two thirds (65\%) of study population was belonging to the age group 30 years. Similarly, about one third of the study population was recorded at age group 30-50 years of age and only $2 \%$ study population was found at age group 50 years and above. Further, this study found higher share of highly educated male adult than female adult. Given Table 1 shows that more than one-half $(57 \%)$ study population was belonging to group of male and remaining about two-thirds $943 \%$ ) study population was found in the group of female.

This study gathered the information regarding caste/ethnic characteristics of study population and found largest population in Brahmin caste. The data presented in Table 1 shows that about more than one-half (54\%) study population was belonging to Brahmin caste and followed by Chhetri (25\%), Adibasi/Janajati/Madesi (18\%) and Dalit 2\%. Similarly, the study also collected the data by religion of study population and found Hinduism as the largest religion group. About nine in tens (90\%) study population were followed Hinduism and only $7 \%$ and 3\% population were followed Buddhism and Christian religion respectively.

Similarly, Table 1 further shows that about more than eight in tens (84\%) population used to speak the Nepali language as a mother tongue and only $5 \%$, and $11 \%$ study population used to speak Tamang language, and other language respectively. Similarly, given table shows the higher percentage of the population had completed a master's level of education. This study found one-third (35\%) share of population. Similar proportion $(34 \%)$ of the population was found in the group of respondents who have completed a bachelor's level of education. Similarly, around one-fourth $(25 \%)$ proportion of the population was found in the group of respondents who have completed +2 level of education and the population who has completed MPhil and Ph.D. level education was found $6 \%$ only. From this information we conclude that the majority 
of the study population found from the group of the members who have completed bachelor's and master's level of education and the members who have studies M.Phil. and Ph.D. level found very little. Among the total no. of respondents 53\% was not involved in the further level of education i.e. this population was not giving continue to education.

We can also learn the information about the reasons for not being able to continue education from the table below. From the given table, we can say that the majority of the study population willing to study the further level of education but their involvement in work is becoming the main obstacle to meet their will. Similarly, a remarkable portion of the study population is not able to meet their will of further education due to the lack of such education services in their access and economic problem. A major reason for not giving continuity to education was found work problems of the respondents. About half of the population (47.2\%) responded that they are not able to take further education due to work problems followed by lack of access $20.8 \%$, economic problems 15.1 , family problem $11.3 \%$, focusing on practice $3.8 \%$, and waiting for the result of entrance $1.9 \%$.

Table 1: Socio-demographic Characteristics of Respondents

\begin{tabular}{llll}
\hline Variables & Responses & frequency & Percentage \\
\hline \multirow{3}{*}{ Age } & Below 30 years & 65 & $65 \%$ \\
$\mathrm{~N}=100$ & $30-50$ years & 33 & $33 \%$ \\
Gender & 50 years and above & 2 & $2 \%$ \\
$\mathrm{~N}=100$ & Male & 57 & $57 \%$ \\
& Female & 43 & $43 \%$ \\
& Adibasi Janajati/ Madesi & 18 & $18 \%$ \\
Caste/ethnicity & Brahmin & 54 & $54 \%$ \\
$\mathrm{~N}=100$ & Chhetri & 25 & $25 \%$ \\
& Dalit & 2 & $2 \%$ \\
Religion & Hinduism & 90 & $90 \%$ \\
$\mathrm{~N}=100$ & Buddhism & 7 & $7 \%$ \\
& Christian & 3 & $3 \%$ \\
Language & Nepali & 84 & $84 \%$ \\
$\mathrm{~N}=100$ & Tamang & 5 & $5 \%$ \\
& Others & 11 & $11 \%$ \\
Education Level & Her Intermediate & 25 & $25 \%$ \\
$\mathrm{~N}=100$ & Bachelor & 34 & $34 \%$ \\
& Master's & 35 & $35 \%$ \\
Continuation Study & Mphil \& Phd & 6 & $6 \%$ \\
$\mathrm{~N}=100$ & Continued & 47 & $47 \%$ \\
& Interrupted & 53 & $53 \%$ \\
Reasons for & Due to economic problem & 8 & $15.1 \%$ \\
\hline & Due to Family problem & 6 & $11.3 \%$ \\
& Due to Lack of access & 11 & \\
& & & $20.8 \%$ \\
\hline
\end{tabular}


International Research Journal of MMC (IRJMMC)

Vol. 2

Issue 1 (February, 2021)

ISSN 2717-4999 (Online)

2717-4980 (Print)

\begin{tabular}{llll}
\hline Interrupting study & Due to work problem & 25 & $47.2 \%$ \\
$\mathrm{~N}=53$ & Focusing on the practices & 2 & $3.8 \%$ \\
& Waiting for entrance & 1 & $1.9 \mid \%$ \\
\hline
\end{tabular}

\section{B. Threats of livelihood in near future life}

Various factors are made for measuring threats of livelihood in the near future of respondents' life. In all factors of treats of livelihood, respondents rate medium threats in the near future of their life except in the factor of the threats of raising the price of goods and services. Respondents rated high threats in the factor of raising the price of goods and services. From the data, we can say that on average all people were living in a society with threats to the basic factors of their livelihoods. In detail, we can learn threats of livelihood of the study population with the help of the following statistics.

Table 4 Degree of threats for the livelihoods in the near future?

\begin{tabular}{cll}
\hline S.N. & \multicolumn{1}{c}{ Factor associated to livelihood threats } & \multicolumn{1}{c}{ Level of threats } \\
\hline 1. & Threats of Unemployment & Medium \\
2. & Threats of declining Income & Medium \\
3. & Threats of raising the price of goods and services & High \\
4. & Threats of sickness of any family members & Medium \\
5. & Threats of loss of assets & Medium \\
6. & Threats of crimes and violence & Medium \\
7. & Threats of safety of school-going children & Medium \\
8. & Threats of safety of women/girls & Medium \\
9. & Threats of harassment by the employer & Medium \\
10. & Threats of family breakup & Medium \\
11. & Threats of natural calamities. & Medium \\
12. & Threats of harassment by officials( including police, politician & Medium \\
13. & Threats of secure future old age life. & \\
\hline
\end{tabular}

Source: Annex I

The above statistics tell that highly educated youths have felt the high threat of rising the price of goods and services in their livelihood in the near future. Similarly, threats are found medium in all categories taken in the study that has been mentioned in the above table among the youth.

\section{Result of hypothesis testing}

In the study, the first hypothesis was made about the significant difference average threats of livelihood by males and females. For the testing hypothesis, Mann-Whitney U Test is used. In doing this p-value was calculated 0.208 as shown in Annex II. P-value tells that the null hypothesis of the test is retained and the alternative hypothesis is rejected. So, the statistical evidence reveals that the average level of threats in livelihood does not vary by male and female 
of the study population. It means the average level of threats in livelihood is the same for males and females.

Similarly, another hypothesis was made about the significant association between threats of livelihood and caste/ethnicity of the study population. For the testing hypothesis, the chisquare test is used. In doing this p-value was calculated 0.298 as shown in Annex II. Such pvalue tells that the null hypothesis is retained and the alternative hypothesis is rejected. So, the statistical evidence proves that there is no significant association between threats in livelihood and caste/ethnicity of the study population. It means both variables; threats of livelihood and caste/ethnicity of the study population are independent.

\section{CONCLUSIONS}

From the study, it was found that all the individuals of the study population have some threats of livelihood in the near future. That treats found high in the factor of increasing the price of goods and services, but in all the factors threats of livelihood found the medium. Some statistical tests also proved that average threats of livelihood do not vary by male and female and the same in both sexes of the study population. Similarly, based on tests used in the study, we can conclude that all individuals have threats of livelihood about their future but their threats do not differ by the group based on different characteristics. At last, we can conclude that threats in livelihood are found in all study population and level of such threats is same in all groups of the population

\section{REFERENCES}

Bebbington, A. (1997). New states, new NGOs? crisis and transition among Andean rural development NGOs. World Development, 25(11), 1755-1765.

Bebbington, A. (1999). Capital and capabilities: A framework for Aanalysing peasant viability, rural livelihoods, and poverty. World Development, 27(12), 203-244.

Carney, D. (Ed.). (1998). Sustainable rural livelihoods: What contribution can we make? London: DFID .

Chambers, R., \& Conway, G. (1992). Sustainable rural livelihoods: Practical concepts for the 21 st century. Institute Development Studies.

Havrda, M., Havrda, M., Clement, \& Clement. (2017). The so-called eighth stromateus by Clement of Alexandria: Early christian reception of Greek scientific methodology. Leiden; Boston: Brill.

Karki, S. (2021). Sustainable livelihood framework: Monitoring and evaluation. International Journal of Social Sciences and Management, , 8(1), 266-271. Retrieved from https://doi.org/10.3126/ijssm.v8i1.34399 
Nair, K.N., Paul, A., \& Menon, V. (2007). Livelihood risks and Ccoping strategies: A case study in the Agrarian Village Of Cherumad, Kerala.

Scooner, I. (1998). Sustainable rurallLivelihoods: A framework for analysis', IDS working Paper No. 72.

Serageldin, I. \&. (Ed.). (1994). Making development sustainable: From concepts to action. The World Bank. Retrieved from https://doi.org/10.1596/0-8213-3042-X

Serrat, O. (2017). The sustainable livelihoods approach. In O. Serrat, Knowledge solutions. Springer Singapore. Retrieved from https://doi.org/10.1007/978-981-10-0983-9_5

Su, F., Saikia, U., \& Hay, I. (2018). Relationships between livelihood risks and livelihood capitals: A case study in Shiyang River Basin, China. Sustainability, 10(2), 1-20. doi:https://doi.org/10.3390/su10020509s

\section{Annex I}

\section{Measurement of level of livelihood threats that perceived by respondents}

\begin{tabular}{|c|c|c|c|c|c|c|c|c|c|}
\hline \multirow{2}{*}{ S.N } & \multirow[t]{2}{*}{ Statements } & \multirow[t]{2}{*}{ Mean } & \multirow[t]{2}{*}{$\mathrm{SD}$} & \multicolumn{5}{|c|}{ Percentage } & \multirow[b]{2}{*}{ Level } \\
\hline & & & & $\mathrm{VL}$ & $\mathrm{L}$ & $\mathrm{A}$ & $\mathrm{H}$ & $\mathrm{VH}$ & \\
\hline 1. & $\begin{array}{l}\text { Threats of } \\
\text { Unemployment }\end{array}$ & 3.03 & 1.218 & 11 & 22 & 37 & 13 & 17 & Medium \\
\hline 2. & $\begin{array}{l}\text { Threats of } \\
\text { declining } \\
\text { Income }\end{array}$ & 2.71 & 1.094 & 13 & 33 & 30 & 18 & 6 & Medium \\
\hline 3. & $\begin{array}{l}\text { Threats of } \\
\text { rising the price } \\
\text { of goods and } \\
\text { services }\end{array}$ & 3.7 & 1.168 & 5 & 11 & 24 & 29 & 31 & High \\
\hline 4. & $\begin{array}{l}\text { Threats of } \\
\text { sickness of any } \\
\text { family members }\end{array}$ & 2.72 & 1.207 & 19 & 27 & 23 & 25 & 6 & Medium \\
\hline 5. & $\begin{array}{l}\text { Threats of loss } \\
\text { of assets }\end{array}$ & 2.56 & 1.149 & 20 & 29 & 34 & 9 & 8 & Medium \\
\hline 6. & $\begin{array}{l}\text { Threats of } \\
\text { crimes and } \\
\text { violence }\end{array}$ & 2.87 & 1.44 & 25 & 17 & 22 & 18 & 18 & Medium \\
\hline 7. & $\begin{array}{l}\text { Threats of safety } \\
\text { of school going } \\
\text { children }\end{array}$ & 3.00 & 1.163 & 12 & 19 & 38 & 19 & 12 & Medium \\
\hline 8. & Threats of safety & 3.14 & 1.198 & 10 & 22 & 25 & 30 & 13 & Medium \\
\hline
\end{tabular}


International Research Journal of MMC (IRJMMC)

Vol. 2 Issue 1 (February, 2021)

ISSN 2717-4999 (Online)

2717-4980 (Print)

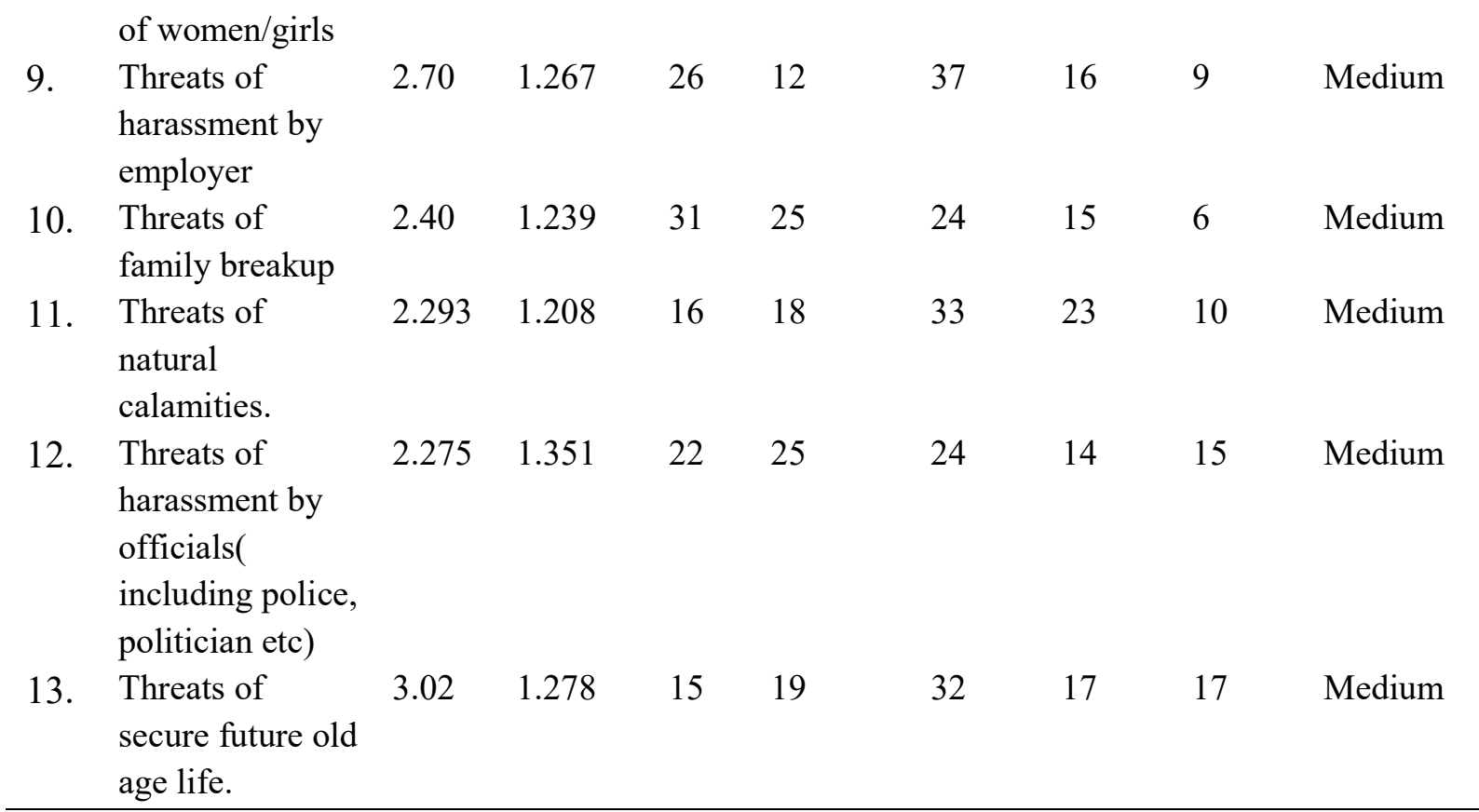

Annex II

1. hypothesis of significant variation in average threats in livelihood by male and female by Mann-Whitney U

\begin{tabular}{cccccccc}
\hline Sex & $\mathrm{N}$ & Mean & Mean rank & SD & $\begin{array}{c}\text { Mann- } \\
\text { Whitney U }\end{array}$ & P-value & $\begin{array}{c}\text { Level of } \\
\text { Significant }\end{array}$ \\
\hline Male & 57 & 2.815 & 47.33 & 0.749 & & & \\
Female & 43 & 2.982 & 54.70 & 0.747 & 1045.000 & 0.298 & Insignificant \\
\hline
\end{tabular}

2. Testing of hypothesis of significant association between caste/ethnicity of respondents and threat of safety of women/girls by Karl Pearson's Chi-square test

\begin{tabular}{ccccccc}
\hline Caste/Ethnicity & $\mathrm{N}$ & Mean & SD & $\begin{array}{c}\text { Chi-square } \\
\text { value }\end{array}$ & P-value & $\begin{array}{c}\text { Level of } \\
\text { Significant }\end{array}$ \\
\hline Brahmin & 54 & 2.866 & 0.819 & & & \\
Chhetri & 25 & 3.015 & 0.733 & \multirow{2}{*}{102.85} & 0.298 & Insignificant \\
Adibasi/Janajati/Madesi & 18 & 2.778 & 0.568 & & & \\
Dalit & 3 & 2.846 & 0.666 & & & \\
\hline
\end{tabular}

